\title{
Weed Management in Soybeans ${ }^{1}$
}

\author{
J. A. Ferrell, G. E. MacDonald, and P. Devkota ${ }^{2}$
}

Successful weed control is one of the most important practices for economical soybean production in Florida. Losses due to weeds have been one of the major limiting factors in soybean production. Weeds compete with soybeans for light, moisture, and nutrients, with early-season competition being the most critical. Most of the yield reduction due to weed competition occurs during the first six weeks after planting; therefore, major emphasis on control should be given during this period. However, producing a good crop of soybeans is only half the battle and will not be profitable unless the soybeans can be harvested. Late-season weeds can result in inefficient equipment operation and excessive harvest losses. Weeds can be controlled in soybeans; however, this requires good management practices in all phases of soybean production. Good weed control involves utilizing all methods available and combining them in an integrated weed management system. This publication discusses weed control methods for soybean growers.

\section{Crop Rotations}

Crop rotations may be beneficial because many of the most troublesome weeds in soybeans (sicklepod, morningglories, cocklebur, and Florida beggarweed) can be more easily controlled in a crop such as corn. If the full benefit of the rotation is to be achieved, weeds must be controlled throughout the growing season of the rotational crop. Weed seeds produced late in the corn season will be available to germinate and compete with the succeeding soybean crop. The major goal of the rotational crop for weed control is to reduce the number of weed seeds available for germination the following season. Other benefits of crop rotation may include reduction of insects, diseases, and nematodes.

\section{Crop Competition}

Crop competition is one of the most important but often overlooked tools in weed control. A good stand of soybeans, which emerge rapidly and shade the row middles early, is helpful in reducing weed competition. Achieving a good stand involves good management practices, such as selection of a well-adapted variety, good fertility, maintenance of proper soil $\mathrm{pH}$, adequate plant populations, and use of narrow but practical row spacings. Utilizing these good management practices is necessary for producing good soybean yields and is also an aid in weed control.

The plant that emerges first and grows most rapidly is usually the plant that will have the competitive advantage; therefore, everything possible should be done to ensure that the soybeans, and not the weeds, have this competitive advantage.

1. This document is SS-AGR-05, one of a series of the Agronomy Department, UF/IFAS Extension. Original publication date January 2000. Revised January 2021. Visit the EDIS website at https://edis.ifas.ufl.edu for the currently supported version of this publication.

2. J. A. Ferrell, professor and director, UF/IFAS Center for Aquatic and Invasive Plants; G. E. MacDonald, professor, Agronomy Department; and P. Devkota, assistant professor, Agronomy Department, UF/IFAS West Florida Research and Education Center; UF/IFAS Extension, Gainesville, FL 32611. Original written by J. A. Ferrell; revised by P. Devkota.

The use of trade names in this publication is solely for the purpose of providing specific information. UF/IFAS does not guarantee or warranty the products named, and references to them in this publication do not signify our approval to the exclusion of other products of suitable composition. Use herbicides safely. Read and follow directions on the manufacturer's label.

The Institute of Food and Agricultural Sciences (IFAS) is an Equal Opportunity Institution authorized to provide research, educational information and other services

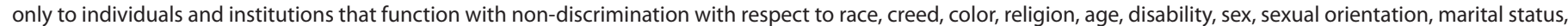

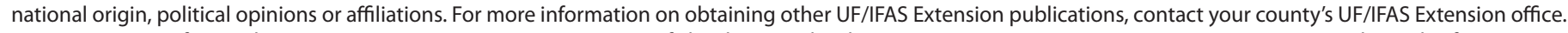
U.S. Department of Agriculture, UF/IFAS Extension Service, University of Florida, IFAS, Florida A \& M University Cooperative Extension Program, and Boards of County Commissioners Cooperating. Nick T. Place, dean for UF/IFAS Extension. 


\section{Cultivation}

Cultivation is still a good and economical method of weed control. However, for cultivation to be effective in controlling weeds in the row, the soybeans must be taller than the weeds. The major reason for cultivation is weed control. Therefore, if an herbicide has resulted in good weed control, then delay cultivation until weeds are present. Only cultivate deeply enough to achieve weed control because deep cultivation may disturb soybean roots, bring weed seeds to the surface, and disturb the layer of soil previously treated with an herbicide.

\section{Know Your Weeds}

Choose control methods that are effective for your specific weed problem. Generally, for preplant and preemergence applications, the weed problems must be anticipated because weeds may not have emerged at the time of application. This can best be done by observing the field in the fall and recording the weeds present as well as their location in the field. These "weed maps" can be very useful in refreshing your memory as you make a decision on what herbicide to purchase the following spring. Before selecting your herbicides (Tables 1-3), identify your expected weed problems. Once your weed problems have been identified, Tables 4 and 5 can be helpful in determining which herbicide is most effective for these weeds.

\section{Herbicides}

Herbicides are one of the most effective tools for weed control in soybeans (Tables 1 and 2). Preplant or preemergence applications combined with the previously discussed management practices are important in ensuring that the soybeans have the initial competitive advantage. One of the problems often encountered during this period is lack of rain to activate surface-applied herbicides. Surface-applied herbicides require rainfall or irrigation to be effective, and for best results, moisture is needed within a week after application. Lack of moisture during this period often results in poor weed control. Incorporated herbicides are not dependent on rainfall or irrigation and have generally given more consistent weed control; however, they do require additional time and equipment for incorporation. Surface-applied herbicides can give excellent control and offer the greatest ease of application, but they also carry the risk of failure without sufficient moisture.

If good initial weed control is achieved with a preplant or preemergence herbicide and the soybeans are taller than the weeds, then other control measures are available to extend the control throughout the season. Over-the-top applications are successful in controlling late-germinating weeds and weeds not controlled by preplant or preemergence herbicides. They can also be used to aid in harvest efficiency.

Tables 4 and 5 can be helpful in choosing the herbicide that is best suited for your particular situation.

\section{Calibration}

Spray equipment should be calibrated accurately. Rates too high may injure the crop, and rates too low may not provide weed control. The herbicides listed in Tables 1 and 2 are those that have performed well in UF/IFAS research at the rates and time of application suggested. Herbicides, like any other pesticide, should be handled with care. Store herbicides behind locked doors, in the original containers, with the label intact, and separated from seed, fertilizer, and other pesticides.

\section{Prepack Mixes}

Several prepack mixes have become registered on soybeans and are legal for use in Florida. Currently, individual active ingredients recommended in this publication can be purchased prepacked in a number of combinations. To list all prepack mixes currently available would be prohibitive in this format. It is important to evaluate the weed problem and consult this fact sheet for individual or tank-mix combinations with good activity. Upon identifying the appropriate active ingredient, shop around to see if the active ingredient or desired active ingredient combination is available in prepack form. Purchasing suitable prepack mixtures can help to reduce costs.

Table 2 shows a list of prepack mixes and active ingredients that are registered for soybeans in Florida.

\section{Herbicide-Resistant Soybeans}

Transgenic or herbicide-resistant soybeans are genetically altered to tolerate herbicides that would normally kill or injure conventional or non-transgenic varieties. This genetic modification allows the use of broad-spectrum herbicides over-the-top of soybeans and provides economical and efficient weed management.

The commercially available transgenic soybean varieties are Roundup Ready and Liberty Link. Using transgenic varieties can expand weed management options while providing a more convenient and effective method of weed control. The following section provides information regarding herbicide applications for Roundup Ready and Liberty 
Link varieties. This is not intended to replace herbicide labels. Read herbicide labels carefully before planting these varieties.

\section{Roundup Ready Soybeans}

Roundup Ready varieties are genetically altered to tolerate over-the-top applications of glyphosate, Roundup WeatherMax, Glyphomax Plus, Glyphomax, Touchdown, and several other products containing glyphosate. Be sure to check the product label for use on all Roundup Ready soybeans. Glyphosate controls most annual grasses and broadleaf weeds. The Roundup Ready system has been most successful where soybeans are drilled in 7- to 10-inch rows, fields are scouted early, and timely applications are made. Producers are encouraged to keep good records of planting to avoid spraying non-transgenic, non-resistant fields with glyphosate. Avoid drift to adjacent crops. Sprayers should be cleaned thoroughly and flushed before and after application.

\section{APPLICATION TIMING}

Glyphosate can be applied anytime from the cracking stage throughout flowering. Multiple applications can be made but should not exceed the recommended limit on the label. Application rates are dependent on weed species and size; therefore, consult the label for this information. Timely application is required. The first application should usually be made 16 to 20 days after planting; repeat applications can be made if needed. In narrow-row soybeans under good growing conditions, a single application is often sufficient. Wide-row soybeans normally require either a preemergence herbicide followed by glyphosate or two postemergence applications.

\section{HERBICIDE PROGRAM}

Any registered soil-applied herbicide can be used on Roundup Ready soybeans. Soil-applied herbicides are generally not needed with timely postemergence applications except for fields with Florida pusley. Use of soil-applied herbicides will, however, make the timing of postemergence herbicides less critical and usually eliminate the need for a second application. Consult the manufacturer label for use rates.

The addition of Cobra or Ultra Blazer will aid in morningglory control. For additional information on the weeds controlled by other herbicides, see Tables 4 and 5 . 
Table 1. Weed management in no-till soybeans.

\begin{tabular}{|l|c|c|c|c|}
\hline $\begin{array}{c}\text { Herbicide Active } \\
\text { Ingredient (Trade/ } \\
\text { Product Names) }\end{array}$ & $\begin{array}{c}\text { Mode of } \\
\text { Action Group } \\
\text { (MoA) }\end{array}$ & $\begin{array}{c}\text { Application Rate } \\
\text { per A (total per A/ } \\
\text { season or year) }\end{array}$ & $\begin{array}{c}\text { Reentry } \\
\text { Interval (REI) }\end{array}$ & \multicolumn{2}{|c|}{ Remarks } \\
\hline $\begin{array}{l}\text { paraquat (Gramoxone } \\
\text { Inteon) }\end{array}$ & 22 & $1-2$ qt & 12 hrs & $\begin{array}{l}\text { For control of most annual weeds and top-kill of } \\
\text { perennials. Apply before, during, or after planting but } \\
\text { prior to emergence of soybeans for control of emerged } \\
\text { vegetation. Good coverage is essential for effective } \\
\text { control. Apply at 40-60 gal/A. Add a surfactant as } \\
\text { recommended on the label. }\end{array}$ \\
\hline $\begin{array}{l}\text { glyphosate } \\
\text { (Various products) }\end{array}$ & 9 & $22-32 \mathrm{fl} \mathrm{oz}$ & $4 \mathrm{hrs}$ & $\begin{array}{l}\text { Apply } 1 \text { qt/A to control annual weeds less than } 6 \text { in tall. } \\
\text { Apply in 10-20 gallons of water per acre. }\end{array}$ \\
\hline
\end{tabular}

Table 2. Soil-applied package mixes for soybeans.

\begin{tabular}{|c|c|c|c|c|}
\hline $\begin{array}{l}\text { Herbicide Active } \\
\text { Ingredient (Trade/ } \\
\text { Product Names) }\end{array}$ & $\begin{array}{c}\text { Mode of Action } \\
\text { Group (MoA) }\end{array}$ & $\begin{array}{l}\text { Application Rate } \\
\text { per A (total per A/ } \\
\text { season or year) }\end{array}$ & $\begin{array}{c}\text { Reentry } \\
\text { Interval (REI) }\end{array}$ & Remarks \\
\hline $\begin{array}{l}\text { metribuzin }+ \\
\text { chlorimuron } \\
\text { (Canopy 75DF) }\end{array}$ & $\begin{array}{l}5 \\
2\end{array}$ & $4-5$ oz & $12 \mathrm{hrs}$ & $\begin{array}{l}\text { Provides good to excellent control of broadleaf } \\
\text { weeds. May be applied preplant incorporated } \\
\text { or preemergence. Rotational restrictions apply. } \\
\text { Consult label for crop rotational guidelines. }\end{array}$ \\
\hline $\begin{array}{l}\text { S-metolachlor }+ \\
\text { metribuzin } \\
\text { (Boundary) }\end{array}$ & $\begin{array}{c}15 \\
5\end{array}$ & $1.0-1.75 \mathrm{pt}$ & $12 \mathrm{hrs}$ & $\begin{array}{l}\text { For broad-spectrum control of grass and } \\
\text { broadleaf weeds. Apply as a preplant } \\
\text { incorporated or preemergence treatment. Soil } \\
\text { moisture is required to activate. Some soybean } \\
\text { varieties are highly sensitive to Boundary; } \\
\text { consult the label for varietal information and } \\
\text { restrictions. Soybeans should be planted } 1.5 \\
\text { inches deep. Applications to sandy soils with } \\
\text { low organic matter will increase soybean injury. }\end{array}$ \\
\hline
\end{tabular}


Table 3. Weed management in soybeans.

\begin{tabular}{|c|c|c|c|c|}
\hline $\begin{array}{l}\text { Herbicide Active } \\
\text { Ingredient (Trade/ } \\
\text { Product Names) }\end{array}$ & $\begin{array}{l}\text { Mode of Action } \\
\text { Group (MoA) }\end{array}$ & $\begin{array}{c}\text { Application Rate per } \\
\text { A (total per A/season } \\
\text { or year) }\end{array}$ & $\begin{array}{l}\text { Reentry } \\
\text { Interval } \\
\text { (REI) }\end{array}$ & Remarks \\
\hline \multicolumn{5}{|c|}{ PREPLANT INCORPORATED } \\
\hline $\begin{array}{l}\text { trifluralin } \\
\text { (Treflan) } \\
\text { or } \\
\text { pendimethalin } \\
\text { (Pendimethalin } 3.3 \\
\text { or } \\
\text { Prowl } \mathrm{H}_{2} \mathrm{O} \text { ) } \\
\text { or } \\
\text { ethafluralin } \\
\text { (Sonalan HFD) }\end{array}$ & 3 & $\begin{array}{c}1-2 \mathrm{pt} \\
\text { or } \\
1.2-1.8 \mathrm{pt} \\
\text { or } \\
2-3 \mathrm{pt} \\
\text { or } \\
1.5-2.0 \mathrm{pt}\end{array}$ & $\begin{array}{c}12 \mathrm{hrs} \\
\text { or } \\
24 \mathrm{hrs} \\
\\
24 \mathrm{hrs}\end{array}$ & $\begin{array}{l}\text { Good control of annual grasses and certain broadleaf } \\
\text { weeds. Poor control of cocklebur, sicklepod (coffeeweed), } \\
\text { morningglory, and ragweed. Does not control nutsedge } \\
\text { spp. Incorporate thoroughly according to label directions. } \\
\text { The spectrum of weeds controlled is similar for each of these } \\
\text { herbicides. }\end{array}$ \\
\hline imazethapyr (Pursuit) & 2 & $1.44 \mathrm{oz}$ & $4 \mathrm{hrs}$ & $\begin{array}{l}\text { Annual grasses, nutsedge, and some broadleaf weeds are } \\
\text { controlled. Poor control of beggarweed, sicklepod, and } \\
\text { ragweed. Excellent on purple nutsedge and wild poinsettia, } \\
\text { good on yellow nutsedge. Pursuit may be applied } \\
\text { PPI, PRE, early-post or postemergence; however, best } \\
\text { nutsedge control is generally achieved with PPI or early- } \\
\text { post treatments. Rotation restrictions: wheat-4 months; } \\
\text { corn-8 months; tobacco-9 months; cotton-18 months. } \\
\text { No restriction for peanuts. }\end{array}$ \\
\hline $\begin{array}{l}\text { imazaquin } \\
\text { (Scepter } 70 \text { DG) }\end{array}$ & 2 & $2.1-2.8 \mathrm{oz}$ & $12 \mathrm{hrs}$ & $\begin{array}{l}\text { For maximum grass control, mix with Treflan, Prowl, or Dual. } \\
\text { Scepter controls cocklebur, jimsonweed, smallflower and } \\
\text { pitted morningglory, pigweeds, wild poinsettia, prickly sida, } \\
\text { and smartweed. Sequential applications of Scepter will } \\
\text { be required to control sicklepod and Florida beggarweed. } \\
\text { Sequential postemergence applications should be applied } \\
\text { before these species exceed the } 1 \text { to } 2 \text { true-leaf stage. The } \\
\text { total amount of Scepter applied per season should not } \\
\text { exceed } 1.33 \text { pt. Rotation restrictions: wheat-3 months; } \\
\text { corn, tobacco-9.5 months; peanuts-11 months; } \\
\text { cotton-18 months. }\end{array}$ \\
\hline \multicolumn{5}{|c|}{ PREEMERGENCE } \\
\hline $\begin{array}{l}\text { S-metolachlor (Dual } \\
\text { Magnum } \\
\text { and others) }\end{array}$ & 15 & $1-1.33 \mathrm{pt}$ & $24 \mathrm{hrs}$ & $\begin{array}{l}\text { Controls annual grasses and certain broadleaf weeds. Poor } \\
\text { control of cocklebur, sicklepod (coffeeweed), morningglory, } \\
\text { and Texas panicum. Apply band or broadcast soon after } \\
\text { planting. Use lower rates on coarse soils. Best results when } \\
\text { rainfall occurs within 4-6 days after application. }\end{array}$ \\
\hline $\begin{array}{l}\text { metribuzin }{ }^{2} \\
\text { (Tricor DF and others) }\end{array}$ & 5 & $0.33-0.5 \mathrm{lb}$ & $12 \mathrm{hrs}$ & $\begin{array}{l}\text { Good control of many broadleaf weeds, especially sicklepod } \\
\text { and hophornbeam copperleaf. The range of crop tolerance } \\
\text { is narrow; therefore, accurate application is critical. Refer } \\
\text { to the label for soil texture and organic matter restrictions. } \\
\text { Applications to sandy soils with low organic matter are } \\
\text { much more likely to result in soybean injury. }\end{array}$ \\
\hline $\begin{array}{l}\text { dimethenamid-P } \\
\text { (Outlook) }\end{array}$ & 15 & $10-18$ oz & $12 \mathrm{hrs}$ & $\begin{array}{l}\text { Similar to metolachlor. Application rate depends on soil } \\
\text { properties. Check label for specific rates. }\end{array}$ \\
\hline $\begin{array}{l}\text { flumioxazin } \\
\text { (Valor SX) }\end{array}$ & 14 & $2-3 o z$ & $12 \mathrm{hrs}$ & $\begin{array}{l}\text { Provides good to excellent control of many annual broadleaf } \\
\text { weeds. Valor will not control grass weeds, nutsedges, } \\
\text { cocklebur, and sicklepod. Apply as a preemergence } \\
\text { treatment only. Do not apply to emerged soybeans. } \\
\text { Should be tank-mixed with Command or Prowl/Pendimax. } \\
\text { Do not use Valor in the same field with Axiom, Domain, } \\
\text { Dual, or Outlook, because severe injury can occur. Valor } \\
\text { can also be tank-mixed with glyphosate in reduced-tillage } \\
\text { production systems. Refer to label for specific rotation } \\
\text { restrictions. }\end{array}$ \\
\hline
\end{tabular}




\begin{tabular}{|c|c|c|c|c|}
\hline $\begin{array}{l}\text { Herbicide Active } \\
\text { Ingredient (Trade/ } \\
\text { Product Names) }\end{array}$ & $\begin{array}{l}\text { Mode of Action } \\
\text { Group (MoA) }\end{array}$ & $\begin{array}{c}\text { Application Rate per } \\
\text { A (total per A/season } \\
\text { or year) }\end{array}$ & $\begin{array}{l}\text { Reentry } \\
\text { Interval } \\
\text { (REI) }\end{array}$ & Remarks \\
\hline $\begin{array}{l}\text { linuron } \\
\text { (Lorox 4L) }\end{array}$ & 7 & $0.6-1.6 \mathrm{pt}$ & $24 \mathrm{hrs}$ & $\begin{array}{l}\text { Provides good control of Florida beggarweed, common } \\
\text { ragweed, and pigweed. Adjust rates depending on soil type. } \\
\text { Sicklepod will not be controlled. Linuron may be tank-mixed } \\
\text { with Dual or Prowl. Plant soybeans at least } 1.5 \text { inches deep } \\
\text { to reduce injury. }\end{array}$ \\
\hline $\begin{array}{l}\text { metribuzin } \\
+ \\
\text { chlorimuron } \\
\text { (Canopy 75DF) }\end{array}$ & $\begin{array}{l}5 \\
2\end{array}$ & $4-5$ oz & $12 \mathrm{hrs}$ & $\begin{array}{l}\text { Good control of several broadleaf weeds, which include } \\
\text { cocklebur, Florida beggarweed, jimsonweed, several } \\
\text { morningglories, prickly sida, and ragweed. May give partial } \\
\text { control of nutsedges and seedling grasses. Crop tolerance } \\
\text { is narrow; therefore, accurate application is critical. Refer } \\
\text { to the Canopy label for soil texture, pH, and organic matter } \\
\text { restrictions. Note recropping intervals and rotational } \\
\text { guidelines on label. See footnote } 1 .\end{array}$ \\
\hline \multicolumn{5}{|c|}{ POSTEMERGENCE HERBICIDES FOR BROADLEAF WEEDS } \\
\hline $\begin{array}{l}\text { bentazon } \\
\text { (Basagran and others) }\end{array}$ & 6 & $1.0-2.0 \mathrm{pt}$ & $48 \mathrm{hrs}$ & $\begin{array}{l}\text { Good to excellent control of certain weeds in the } 2-6 \\
\text { leaf stage, such as cocklebur, ragweed, morningglory, } \\
\text { and yellow nutsedge. Use low rate on small weeds. Two } \\
\text { applications at the low rate may be needed for yellow } \\
\text { nutsedge control. Early treatment and good spray coverage } \\
\text { are needed for best results. Soybeans have excellent } \\
\text { tolerance. Always apply a crop oil concentrate }(0.125 \%- \\
0.75 \% \mathrm{v} / \mathrm{v}) \text {. }\end{array}$ \\
\hline $\begin{array}{l}\text { acifluorfen } \\
\text { (Ultra Blazer) }\end{array}$ & 14 & $0.5-1.5 \mathrm{pt}$ & $48 \mathrm{hrs}$ & $\begin{array}{l}\text { Good to excellent control of many broadleaf weed species. } \\
\text { Refer to the label for the proper rate for each species. Apply } \\
\text { over-the-top after beans reach the first trifoliate stage and } \\
\text { before the weeds are } 4 \text { inches tall. Sprayed leaves may be } \\
\text { crinkled or cupped, but new leaves should be unaffected. } \\
\text { Add a surfactant at the rate recommended on the label. Do } \\
\text { not apply if plants are drought stressed. May be tank-mixed } \\
\text { with several herbicides. Consult product labels for specifics. }\end{array}$ \\
\hline $\begin{array}{l}\text { chlorimuron ethyl } \\
\text { (Classic } 25 \text { DF) }\end{array}$ & 2 & $0.5-0.75 \mathrm{oz}$ & $12 \mathrm{hrs}$ & $\begin{array}{l}\text { Apply Classic as a postemergence treatment anytime after } \\
\text { the first trifoliate has opened but no later than } 60 \text { days } \\
\text { before maturity. Controls weeds } 2-4 \text { inches in size that } \\
\text { are actively growing, and without environmental stress. } \\
\text { Weeds controlled include bristly starbur, cocklebur, Florida } \\
\text { beggarweed, jimsonweed, pigweed, ragweed, smartweed, } \\
\text { and yellow nutsedge. A second application at } 0.5 \text { oz/A may } \\
\text { be made } 2-3 \text { weeks after the initial application if conditions } \\
\text { warrant. Postemergence applications of Classic should } \\
\text { include a nonionic surfactant ( } 80 \% \text { active) at } 1 \text { qt per } 100 \\
\text { gal of spray mixture. Strict recropping intervals apply. Check } \\
\text { the label for application specifics and recropping schedules. }\end{array}$ \\
\hline $\begin{array}{l}\text { lactofen } \\
\text { (Cobra 2EC) }\end{array}$ & 14 & $10-12.5 \mathrm{oz}$ & $12 \mathrm{hrs}$ & $\begin{array}{l}\text { Good to excellent control of many broadleaf weed species. } \\
\text { Refer to label for the proper rate for each species. Apply } \\
\text { over-the-top when soybeans are at the first or second } \\
\text { trifoliate leaf stage and weeds are } 3-4 \text { inches tall. Sprayed } \\
\text { leaves may show some cupping at the tip and crinkled } \\
\text { edges, but will soon outgrow this damage under good } \\
\text { conditions. Always apply a nonionic surfactant }(0.25 \% \mathrm{v} / \mathrm{v}) \\
\text { or a crop oil concentrate }(0.125 \%-0.75 \% \mathrm{v} / \mathrm{v}) \text { with Cobra } \\
\text { herbicide. Cobra will exhibit more crop injury than Ultra } \\
\text { Blazer. }\end{array}$ \\
\hline
\end{tabular}




\begin{tabular}{|c|c|c|c|c|}
\hline $\begin{array}{l}\text { Herbicide Active } \\
\text { Ingredient (Trade/ } \\
\text { Product Names) }\end{array}$ & $\begin{array}{l}\text { Mode of Action } \\
\text { Group (MoA) }\end{array}$ & $\begin{array}{l}\text { Application Rate per } \\
\text { A (total per } A / \text { season } \\
\text { or year) }\end{array}$ & $\begin{array}{l}\text { Reentry } \\
\text { Interval } \\
\text { (REI) }\end{array}$ & Remarks \\
\hline $\begin{array}{l}\text { cloransulam-methyl } \\
\text { (Firstrate 84WDG) }\end{array}$ & 2 & $0.3-0.8 \mathrm{oz}$ & $12 \mathrm{hrs}$ & $\begin{array}{l}\text { May be applied at any time prior to } 50 \% \text { flowering stage. } \\
\text { Temporary yellowing of soybeans may occur in applications } \\
\text { made before full emergence of the first trifoliate leaf. See } \\
\text { label for tank mixes. Add a crop oil concentrate at } 1.2 \% \mathrm{v} / \mathrm{v} \text {. } \\
\text { Provides good control of cocklebur and sicklepod. Rotation } \\
\text { restrictions: } 9 \text { months (corn, cotton, peanut, sorghum), } 18 \\
\text { months (sweet corn), } 30 \text { months (tobacco). }\end{array}$ \\
\hline $\begin{array}{l}\text { imazethapyr } \\
\text { (Pursuit) }\end{array}$ & 2 & $4 \mathrm{oz}$ & $4 \mathrm{hrs}$ & $\begin{array}{l}\text { Pursuit may be applied anytime after soybean emergence, } \\
\text { but before weeds exceed } 3 \text { inches. Add } 0.25 \% \text { of a nonionic } \\
\text { surfactant ( } 2 \mathrm{pt} / 100 \text { gal of spray mixture). After application, } \\
\text { wait at least } 10 \text { days before cultivation. Do not apply } \\
\text { Pursuit if Canopy, Scepter, or Pursuit was used as a preplant } \\
\text { incorporated or preemergence treatment. }\end{array}$ \\
\hline flumiclorac (Resource) & 14 & $4 \mathrm{oz}$ & $12 \mathrm{hrs}$ & $\begin{array}{l}\text { Tank-mix with glyphosate for improved control of tall, } \\
\text { ivyleaf, and entireleaf morningglory in Roundup Ready } \\
\text { soybeans only. Must be applied with a NIS }(0.25 \% \text { v/v) or } \\
\text { COC ( } 1 \text { pt/A). }\end{array}$ \\
\hline $\begin{array}{l}\text { imazaquin } \\
\text { (Scepter } 70 \text { DG) }\end{array}$ & 2 & $1.4-2.8 \mathrm{oz}$ & $12 \mathrm{hrs}$ & $\begin{array}{l}\text { Apply Scepter as a postemergence treatment after crop } \\
\text { emergence but before weeds exceed a height of } 12 \text { inches. } \\
\text { Apply when weeds are actively growing. The addition of } 1 \\
\text { qt of nonionic surfactant ( } 80 \% \text { active) per } 100 \text { gal of spray } \\
\text { mixture is required. Weeds controlled include cocklebur, } \\
\text { pigweeds, and wild poinsettia. If postemergence treatment } \\
\text { is in a sequential application scheme for the control of } \\
\text { sicklepod or Florida beggarweed, a spray application should } \\
\text { be made before these species exceed the } 1-2 \text { true leaf } \\
\text { stage. }\end{array}$ \\
\hline $\begin{array}{l}\text { bentazon } \\
+ \\
\text { acifluorfen } \\
\text { (Storm) }\end{array}$ & $\begin{array}{c}6 \\
14\end{array}$ & $1.5 \mathrm{pt}$ & $48 \mathrm{hrs}$ & $\begin{array}{l}\text { Apply to actively growing weeds while soybeans are in the } \\
2-3 \text { trifoliate stage. A nonionic surfactant ( } 1-2 \text { pt } / 100 \text { gal) } \\
\text { or crop oil concentrate must be added. May be tank-mixed; } \\
\text { consult label. }\end{array}$ \\
\hline \multicolumn{5}{|c|}{ POSTEMERGENCE GRASS HERBICIDES } \\
\hline $\begin{array}{l}\text { fluazifop-butyl } \\
\text { (Fusilade DX) }\end{array}$ & 1 & $6-12 \mathrm{oz}$ & $12 \mathrm{hrs}$ & $\begin{array}{l}\text { Apply for control of most annual and perennial grasses } \\
\text { before they exceed } 4 \text { inches in height. See label for specific } \\
\text { rates and weeds. Add crop oil concentrate }(1 \mathrm{gal}) \text { or } \\
\text { nonionic surfactant ( } 2 \text { pt) per } 100 \text { gal spray mixture. }\end{array}$ \\
\hline $\begin{array}{l}\text { sethoxydim } \\
\text { (Poast } \\
\text { or } \\
\text { Poast Plus) }\end{array}$ & 1 & $\begin{array}{l}1.0-1.5 \mathrm{pt} \\
\text { or } \\
1.5-2.25 \mathrm{pt}\end{array}$ & $12 \mathrm{hrs}$ & $\begin{array}{l}\text { Apply for control of most annual and perennial grasses, } \\
\text { before grasses exceed a height of } 4 \text { inches. Include a crop oil } \\
\text { concentrate at } 2 \text { pt/A. Poast is less effective than Fusilade on } \\
\text { bermudagrass. }\end{array}$ \\
\hline $\begin{array}{l}\text { clethodim } \\
\text { (Clethodim 2EC } \\
\text { or } \\
\text { Select Max or TapOut) }\end{array}$ & 1 & $\begin{array}{l}6-16 \mathrm{oz} \\
\text { or } \\
9-32 \mathrm{oz}\end{array}$ & $12 \mathrm{hrs}$ & $\begin{array}{l}\text { Apply for the control of annual and perennial grasses. For } \\
\text { annual grasses up to } 6 \text { inches tall, apply the lower use rates. } \\
\text { A second application may be made. Higher rates will be } \\
\text { necessary for rhizome johnsongrass, bermudagrass, and } \\
\text { other perennial grasses. Add crop oil concentrate at } 1 \mathrm{gal} \\
\text { per } 100 \text { gal of spray mixture. Select Max can be sprayed with } \\
\text { either surfactant or crop oil. Do not apply more than } 32 \mathrm{oz} \\
\text { of Select or } 64 \text { oz of Select Max per acre per year. }\end{array}$ \\
\hline \multicolumn{5}{|c|}{ TRANSGENIC SOYBEANS } \\
\hline $\begin{array}{l}\text { glufosinate } \\
\text { (Liberty 280) }\end{array}$ & 10 & $29-36$ oz & $12 \mathrm{hrs}$ & $\begin{array}{l}\text { Apply only to soybeans designated as Liberty Link. Can be } \\
\text { applied from emergence until blooming. Do not apply more } \\
\text { than } 62 \text { oz/A/yr. Very effective on morningglory, Florida } \\
\text { pusley, and cutleaf eveningprimrose. Less effective on } \\
\text { grasses and sedges. }\end{array}$ \\
\hline
\end{tabular}




\begin{tabular}{|c|c|c|c|c|}
\hline $\begin{array}{l}\text { Herbicide Active } \\
\text { Ingredient (Trade/ } \\
\text { Product Names) }\end{array}$ & $\begin{array}{l}\text { Mode of Action } \\
\text { Group (MoA) }\end{array}$ & $\begin{array}{l}\text { Application Rate per } \\
\text { A (total per A/season } \\
\text { or year) }\end{array}$ & $\begin{array}{l}\text { Reentry } \\
\text { Interval } \\
\text { (REI) }\end{array}$ & Remarks \\
\hline $\begin{array}{l}\text { glyphosate } \\
\text { (Several products and } \\
\text { formulations) }\end{array}$ & 9 & $22-32 \mathrm{fl} \mathrm{oz}$ & $4 \mathrm{hrs}$ & $\begin{array}{l}\text { Apply glyphosate over-the-top of improved soybean } \\
\text { varieties that are designated as Roundup Ready } \\
\text { soybeans only. Otherwise, severe soybean injury or death } \\
\text { will result. Controls a wide range of grass and broadleaf } \\
\text { weeds. May be applied from the cracking stage through } \\
\text { the full-flowering stage of soybeans. Use the low rate } \\
\text { on weeds up to } 3 \text { inches tall. Higher rates are needed as } \\
\text { weeds increase in size. Applications should be made when } \\
\text { morningglories are less than } 3 \text { inches tall. Sequential } \\
\text { treatments may be applied, provided that the maximum } \\
\text { postemergence (from cracking to flowering) total use rate } \\
\text { does not exceed } 3.0 \text { quarts per acre of } 4 \mathrm{lb} / \text { gal products, } \\
2.4 \text { qt/A of } 5 \text { lb/gal products, or } 2 \text { qt of } 5.5 \mathrm{lb} / \text { gal products. } \\
\text { No additional surfactant is necessary. There are no crop } \\
\text { rotational restrictions for glyphosate. Not all formulations } \\
\text { are labeled for use on RR soybeans. Refer to the specific } \\
\text { product label. }\end{array}$ \\
\hline $\begin{array}{l}\text { dicamba } \\
\text { (Xtendimax, Engenia, } \\
\text { Fexapan, or Tavium) }\end{array}$ & 4 & $22 \mathrm{fl} \mathrm{oz}$ & $24 \mathrm{hrs}$ & $\begin{array}{l}\text { Apply only on the XtendFlex soybean. } \\
\text { Follow the respective herbicide label for detailed } \\
\text { information. }\end{array}$ \\
\hline $\begin{array}{l}\text { 2,4-D } \\
\text { (Enlist One } \\
\text { or } \\
\text { Enlist Duo) }\end{array}$ & $\begin{array}{c}4 \\
4+9\end{array}$ & $\begin{array}{l}1.5-2 \mathrm{pt} \\
\text { or } \\
3.5-4.75 \mathrm{pt}\end{array}$ & $48 \mathrm{hrs}$ & $\begin{array}{l}\text { Apply only to Enlist or Enlist E3 soybeans. } \\
\text { Follow the respective herbicide label for detailed } \\
\text { information. }\end{array}$ \\
\hline \multicolumn{5}{|c|}{ HARVEST AID } \\
\hline $\begin{array}{l}\text { carfentrazone } \\
\text { (Aim 2EC) }\end{array}$ & 14 & $1.5 \mathrm{fl} \mathrm{oz}$ & $12 \mathrm{hrs}$ & $\begin{array}{l}\text { Apply after grain has started to dry out. Apply more than } 10 \\
\text { GPA for maximum coverage. Add crop oil at } 1 \mathrm{gal} / 100 \mathrm{gal} \\
\text { solution, NIS at } 1 \mathrm{qt} / 100 \mathrm{gal} \text { solution, or MSO at } 1-2 \mathrm{gal} / 100 \\
\text { gal solution. Do not apply to wet soybean foliage. Rainfast } \\
\text { interval of } 6-8 \text { hours. Preharvest interval (PHI) of } 3 \text { days. }\end{array}$ \\
\hline $\begin{array}{l}\text { sodium chlorate } \\
\text { (Defol 750) }\end{array}$ & - & $3.2 \mathrm{qt}$ & $12 \mathrm{hrs}$ & $\begin{array}{l}\text { PHI of } 7-10 \text { days. Apply to mature soybeans. Apply at } \\
\text { least } 20 \text { GPA for good coverage. Use NIS at } 2-4 \text { pt/100 gal } \\
\text { solution. Rainfast interval of } 24 \mathrm{hrs} \text {. }\end{array}$ \\
\hline $\begin{array}{l}\text { paraquat (Gramoxone } \\
\text { SL } 2.0 \text { and others) }\end{array}$ & 22 & 8-16 fl oz & $12 \mathrm{hrs}$ & $\begin{array}{l}\text { This is a harvest-aid treatment. Apply when half of the } \\
\text { soybean leaves have dropped and the remaining half are } \\
\text { yellow. Earlier applications will reduce yields. Harvest can } \\
\text { begin } 6-10 \text { days after application. Weeds such as hairy } \\
\text { indigo will not be desiccated by this treatment. Use as } \\
\text { surfactant. }\end{array}$ \\
\hline \multicolumn{5}{|c|}{$\begin{array}{l}\text { ' WARNING: THE FOLLOWING STATEMENT HAS BEEN ADDED TO THE SENCOR/CANOPY LABEL. THIS STATEMENT SHOULD BE HEEDED BY ALL } \\
\text { PROSPECTIVE USERS AND STEPS SHOULD BE TAKEN TO COMPLY WITH THIS LABEL CHANGE. SENCOR/LEXONE IS A CHEMICAL WHICH CAN } \\
\text { TRAVEL (SEEP OR LEACH) THROUGH SOIL AND CAN CONTAMINATE GROUND WATER AS A RESULT OF AGRICULTURAL USE. SENCOR/LEXONE } \\
\text { HAS BEEN FOUND IN GROUND WATER AS A RESULT OF AGRICULTURAL USE. USERS ARE ADVISED NOT TO APPLY SENCOR/LEXONE WHERE THE } \\
\text { WATER TABLE (GROUND WATER) IS CLOSE TO THE SURFACE AND WHERE THE SOILS ARE VERY PERMEABLE, I.E., WELL-DRAINED SOILS SUCH AS } \\
\text { LOAMY SANDS. YOUR LOCAL AGRICULTURAL AGENCIES CAN PROVIDE FURTHER INFORMATION ON THE TYPE OF SOIL IN YOUR AREA AND THE } \\
\text { LOCATION OF GROUND WATER. IN ADDITION, SOME PRODUCT LABEL STATEMENTS INCLUDE AS A FURTHER QUALIFICATION OF RISKY SOILS, } \\
\text { SOILS CONTAINING SINKHOLES OVER LIMESTONE BEDROCK, SEVERELY FRACTURED SURFACES, AND SUBSTRATES WHICH WOULD ALLOW } \\
\text { DIRECT INTRODUCTION INTO AN AQUIFER. } \\
{ }^{2} \text { Metribuzin is not recommended for use on AP 55, AP 71, Burlison, Dassel, Tracy, Semmes, Altona, Vansoy, Coker } 102, \text { or Coker } 156 \text { soybeans: } \\
\text { See the product label for the complete list of soybean cultivars. Crop injury may occur when metribuzin is used in conjunction with soil- } \\
\text { applied organophosphate pesticides, such as Counter, Dasanit, etc. }\end{array}$} \\
\hline
\end{tabular}


Table 4. Estimated effectiveness of recommended herbicides on common weeds in Florida. ${ }^{1}$

\begin{tabular}{|c|c|c|c|c|c|c|c|c|}
\hline Herbicides & $\begin{array}{l}\text { Treflan, } \\
\text { Prowl, } \\
\text { Sonalan }\end{array}$ & Scepter & Pursuit & Prowl & Canopy & $\begin{array}{c}\text { Dual } \\
\text { Magnum }\end{array}$ & First Rate & Scepter \\
\hline Time of Application & PPI & PPI & PPI & PRE & PRE & PRE & PPI/PRE & POT \\
\hline \multicolumn{9}{|c|}{ WEEDS } \\
\hline \multicolumn{9}{|c|}{ BROADLEAF } \\
\hline Bristly starbur & $\mathrm{P}$ & $\mathrm{F}$ & $\mathrm{F}$ & $\mathrm{P}$ & G & $P$ & $E$ & - \\
\hline Crotalaria & $P$ & $\mathrm{~F}$ & $\mathrm{~F}$ & $P$ & - & $P$ & - & - \\
\hline Cocklebur & $\mathrm{P}$ & $E$ & G-E & $P$ & $E$ & $\mathrm{P}$ & $E$ & $E$ \\
\hline Florida beggarweed & $\mathrm{P}$ & $\mathrm{F}$ & $P$ & $\mathrm{P}$ & $\mathrm{E}$ & $\mathrm{F}$ & $\mathrm{F}-\mathrm{G}$ & $\mathrm{F}$ \\
\hline Florida pusley & $\mathrm{E}$ & $\mathrm{E}$ & $\mathrm{E}$ & $\mathrm{E}$ & $\mathrm{E}$ & $\mathrm{G}-\mathrm{E}$ & $E$ & $\mathrm{P}$ \\
\hline Morningglory & $\mathrm{P}$ & G & $\mathrm{F}-\mathrm{G}$ & $P$ & G & $\mathrm{P}$ & G & $\mathrm{F}-\mathrm{G}^{2}$ \\
\hline Pigweed & $E$ & $E$ & G & G & $E$ & $E$ & $\mathrm{P}$ & $E$ \\
\hline Ragweed & $P$ & $\mathrm{~F}-\mathrm{G}$ & $P$ & $P$ & $\mathrm{E}$ & $\mathrm{F}$ & $\mathrm{E}$ & - \\
\hline Sicklepod (coffeeweed) & $P$ & $\mathrm{~F}$ & $P$ & $P$ & $E$ & $P$ & $\mathrm{~F}$ & $\mathrm{G}^{3}$ \\
\hline Smartweed & $\mathrm{P}$ & G & $\mathrm{P}-\mathrm{F}$ & $P$ & G & $\mathrm{P}$ & - & - \\
\hline Wild poinsettia & $P$ & G & $\mathrm{G}-\mathrm{E}$ & $P$ & $\mathrm{~F}-\mathrm{G}$ & $\mathrm{P}-\mathrm{F}$ & G & $\mathrm{E}$ \\
\hline \multicolumn{9}{|c|}{ GRASS } \\
\hline Jungle rice/barnyardgrass & $\mathrm{E}$ & $\mathrm{F}$ & $\mathrm{F}$ & G & - & $\mathrm{E}$ & $\mathrm{P}$ & $\mathrm{P}$ \\
\hline Crabgrass & $E$ & $\mathrm{~F}$ & $\mathrm{~F}$ & G & G & $E$ & $P$ & $P$ \\
\hline Fall panicum & $\mathrm{G}-\mathrm{E}$ & $\mathrm{F}$ & $\mathrm{F}$ & G & $\mathrm{F}$ & G & $\mathrm{P}$ & $\mathrm{P}$ \\
\hline Goosegrass & $\mathrm{E}$ & $\mathrm{F}$ & $\mathrm{F}$ & G & G & $\mathrm{E}$ & $\mathrm{P}$ & $\mathrm{P}$ \\
\hline Johnsongrass (seed) & $E$ & $\mathrm{~F}$ & $\mathrm{~F}$ & G & $\mathrm{F}$ & $\mathrm{F}$ & $\mathrm{P}$ & $\mathrm{P}$ \\
\hline Sandbur & $E$ & $\mathrm{~F}$ & $\mathrm{~F}$ & G & $\mathrm{F}$ & G & $\mathrm{P}$ & $\mathrm{P}$ \\
\hline Johnsongrass (rhizome) & $\mathrm{P}$ & $\mathrm{P}$ & $\mathrm{P}$ & $\mathrm{P}$ & $\mathrm{P}$ & $\mathrm{P}$ & $\mathrm{P}$ & $\mathrm{P}$ \\
\hline Texas panicum & $\mathrm{E}$ & $\mathrm{P}$ & $\mathrm{P}-\mathrm{F}$ & $\mathrm{G}-\mathrm{E}$ & $\mathrm{F}$ & $\mathrm{P}$ & $\mathrm{P}$ & $\mathrm{P}$ \\
\hline \multicolumn{9}{|c|}{ SEDGES } \\
\hline Purple nutsedge & $\mathrm{P}$ & $\mathrm{F}$ & G-E & $\mathrm{P}$ & $\mathrm{P}$ & $\mathrm{F}$ & $\mathrm{P}$ & $\mathrm{P}-\mathrm{F}$ \\
\hline Yellow nutsedge & $P$ & $\mathrm{~F}$ & G & $P$ & $\mathrm{P}$ & $\mathrm{F}$ & $P$ & $\mathrm{P}-\mathrm{F}$ \\
\hline \multicolumn{9}{|c|}{$\begin{array}{l}{ }^{1} \text { Estimated effectiveness based on herbicide rates recommended in this report. Effectiveness may vary depending on factors such as } \mathrm{h} \\
\text { rate, size of weeds, time of application, soil type, and weather conditions. } \\
{ }^{2} \text { Check label for particular species control differences. } \\
{ }^{3} \text { Must follow a sequential PPI Scepter treatment. } \\
\text { Weed Control Symbols: E = } 90 \%-100 \% \text { control; } G=80 \%-90 \% \text { control; F }=60 \%-80 \% \text { control; } P=\text { less than } 60 \% \text { control; - = insufficient } \\
\text { observations. } \\
\text { Time of Application: PPI = preplant; PRE = preemergence; POT = postemergence over the top. }\end{array}$} \\
\hline
\end{tabular}


Table 5. Estimated effectiveness of recommended herbicides on common weeds in Florida soybeans (cont.). ${ }^{1}$

\begin{tabular}{|c|c|c|c|c|c|c|}
\hline Herbicides & Glyphosate* & Basagran & Classic & $\begin{array}{l}\text { Gramoxone } \\
\text { Inteon }\end{array}$ & $\begin{array}{c}\text { Ultra Blazer, } \\
\text { Cobra }\end{array}$ & $\begin{array}{c}\text { Poast Plus, } \\
\text { Fusilade, Select, or } \\
\text { Assure II }\end{array}$ \\
\hline Time of Application & POT & POT & POT & PDS & POT & POT \\
\hline \multicolumn{7}{|c|}{ WEEDS } \\
\hline \multicolumn{7}{|c|}{ BROADLEAF } \\
\hline Bristly starbur & G-E & $E$ & $E$ & G-E & $\mathrm{P}-\mathrm{F}$ & $P$ \\
\hline Crotalaria & $F-G$ & $P$ & - & G-E & $\mathrm{E}$ & $P$ \\
\hline Cocklebur & $\mathrm{E}$ & $E$ & $E$ & $E$ & $E$ & $P$ \\
\hline Florida beggarweed & G & $\mathrm{P}$ & G & $\mathrm{G}-\mathrm{E}$ & P-F & $\mathrm{P}$ \\
\hline Florida pusley & $\mathrm{P}$ & $P$ & $P$ & $P$ & $P$ & $\mathrm{P}$ \\
\hline Morningglory & $F-G$ & $F-G$ & $\mathrm{G}^{2}$ & G & $E$ & $\mathrm{P}$ \\
\hline Pigweed & G-E & G & $\mathrm{E}$ & G-E & $\mathrm{E}$ & $\mathrm{P}$ \\
\hline Ragweed & G & $F-G$ & $E$ & G-E & $E$ & $P$ \\
\hline Sicklepod (coffeeweed) & $\mathrm{G}-\mathrm{E}$ & $\mathrm{P}$ & G & $\mathrm{G}-\mathrm{E}$ & $P$ & $\mathrm{P}$ \\
\hline Smartweed & G & - & $E$ & $\mathrm{~F}$ & $\mathrm{~F}$ & $\mathrm{P}$ \\
\hline Wild poinsettia & G-E & $\mathrm{P}$ & G & $\mathrm{F}$ & $F-G$ & $\mathrm{P}$ \\
\hline \multicolumn{7}{|c|}{ GRASS } \\
\hline Jungle rice/barnyardgrass & G & $\mathrm{P}$ & $\mathrm{P}$ & $E$ & $\mathrm{P}$ & G-E \\
\hline Crabgrass & $E$ & $\mathrm{P}$ & $P$ & $E$ & $P$ & $E$ \\
\hline Fall panicum & $\mathrm{E}$ & $\mathrm{P}$ & $P$ & $\mathrm{E}$ & $P$ & $\mathrm{G}-\mathrm{E}$ \\
\hline Goosegrass & $\mathrm{E}$ & $\mathrm{P}$ & $\mathrm{P}$ & $E$ & $\mathrm{P}$ & G-E \\
\hline Johnsongrass (seed) & $\mathrm{E}$ & $P$ & $\mathrm{P}$ & $\mathrm{E}$ & $P$ & G-E \\
\hline Sandbur & G & $\mathrm{P}$ & $P$ & $\mathrm{E}$ & $\mathrm{P}$ & G-E \\
\hline Johnsongrass (rhizome) & $\mathrm{E}$ & $\mathrm{P}$ & $\mathrm{P}$ & $\mathrm{P}$ & $P$ & G \\
\hline Texas panicum & $E$ & $\mathrm{P}$ & $P$ & $E$ & $\mathrm{P}$ & $\mathrm{G}-\mathrm{E}$ \\
\hline \multicolumn{7}{|c|}{ SEDGES } \\
\hline Purple nutsedge & $F-G$ & $\mathrm{P}$ & $\mathrm{F}$ & $\mathrm{F}$ & $\mathrm{P}$ & $\mathrm{P}$ \\
\hline Yellow nutsedge & $\mathrm{F}-\mathrm{G}$ & G & $\mathrm{F}$ & $\mathrm{F}$ & $P$ & $P$ \\
\hline \multicolumn{7}{|c|}{$\begin{array}{l}{ }^{1} \text { Estimated effectiveness based on herbicide rates recommended in this report. Effectiveness may vary depending on factors such as he } \\
\text { rate, size of weeds, time of application, soil type, and weather conditions. } \\
{ }^{2} \text { Check label for particular species control differences. } \\
{ }^{*} \text { Glyphosate can be used ONLY on Roundup Ready soybeans. } \\
\text { Weed Control Symbols: E = } 90 \%-100 \% \text { control; G }=80 \%-90 \% \text { control; } F=60 \%-80 \% \text { control; P = less than } 60 \% \text { control; - = insufficient } \\
\text { observations. } \\
\text { Time of Application: PPI = preplant; PRE = preemergence; POT = postemergence over the top; PDS = postemergence directed. }\end{array}$} \\
\hline
\end{tabular}

